\title{
Lausunto Hannu Valkaman lisensiaattitutkielmasta Strateginen kehittäminen koulutusorganisaatiossa, Malli muutoksen johtamiseen
}

$\mathbf{H}$ annu Valkaman tutkimus on osa laajempaa projektia, jossa haetaan ajatuksellisia välineitä koulutusorganisaatioiden ja niiden toimintaympäristön vuorovaikutuksen hallintaan". Tutkielma soveltuu erinomaisesti aikuiskasvatuksen opinnäytteeksi; siinä yhdistyvät poikkeuksellisen saumattomasti toisiinsa teoreettinen orientoituminen ja pyrkimys vastata käytännön koulutussuunnittelun ajankohtaisiin kehittämisvaatimuksiin. Vaikka raportti käsittää vain alkuosan edelleen jatkuvasta tutkimushankkeesta, siinä esitelty kehittämismallin muodostaminen on oma selväpiirteinen, lisensiaattityöksi riittävän laaja ja vaativa kokonaisuutensa.

Tutkimus liittyy koulutusprojektiin, jota on toteutettu Helsingin ylipiston Vantaan täydennyskoulutuslaitoksen ja kolmen ammatillisen koulutuskuntainliiton yhteistyönä keväästä 1989 alkaen. Valkaman nyt raportoima osatutkimus käsittää sekä mallin teoreettisen rakentamisen että sen koettelun ja konkretisoimisen projektiin kuuluneen koulutustoiminnan yhteydessä.

Mallin muodostamista ja koulutusprojektin toteuttamista yhdistävänä viitekehyksenä on tekijän mukaan toiminut kehittävän työntutkimuksen metodologia. Tutkimusprosessi samoin kuin siinä monessa suhteessa engeströmiläisestä kehittävän työntutkimuksen strategisen suunnittelun ja muutoksen johtamisen lähestymistavoista ja toisaalta teoriakehitelmistä, joissa organisaation kehittäminen ja oppiminen pyritään yhdistämään samaksi prosessiksi. Päämääränä on ollut rakentaa "'metodologista siltaa varsin erilaisten ajattelutraditioiden välille"'. Tässä tekijä on ainakin teoreettisen ajattelun tasolla onnistunut kiitosta ansaitsevalla tavalla. Mallin toimivuutta ei tutkimuksen tässä vaiheessa voida vielä arvioida kuin alustavien havaintojen varassa.

Mallin ja sen rakentamistavan yksityiskohtainen esittely veisi lausunnossa liiaksi tilaa. Sen yksi keskeinen ratkaisu on, että kehittämistyö eriytetään organisaation jokapäiväisestä toiminnasta erkaantuvaksi, mutta siihen toistuvasti paalaavaksi sykliksi. Strategisen kehittämisen prosessissa on kolme päävaihetta: yhteisen näkemyksen muodostaminen muutoksen tarpeesta ja sen toteuttamisen edellytyksistä, muutosedellytysten tuottaminen ja muutoksen toteuttaminen, arviointi ja vakiinnuttaminen.

Mallin koettelu ja konkretisoiva kehittely tapahtuu koulutusprojektin avulla. Koettelu ei tässä tarkoita mallin järjestelmällistä soveltamista käytäntöön, vaan testaus on pääasiallisesti tapahtunut kuntainliittojen johtoryhmien koulutustilaisuuksissa, joissa mallia on käyty läpi ja osallistujat tehneet siitä omat arviointinsa sekä organisaatioissa parhaillaan vireillä olleiden kehittämishankkeitten tarjoamien että muiden kokemustensa perustalla. Osallistujat suorittivat ennakko- ja välitehtäviä kolmen koulutustilaisuuden lomassa ja tekivät lomakemuotoisena toteutetun mallin arvioinnin. Tämän aineiston kokoamista ja käsittelyä voidaan nimittää tutkimuksen empiiriseksi osaksi. Koettelu ei ollut kovin perusteellinen; kaikkiaan nämä parikymmentä osallistujaa arvioivat käyttäneensä ' kehittämissyklin analyysivaiheeseen' aikaa 5-6 työpäivän verran kukin.

Koulutusvaiheita ja niihin liittynyttä muuta toimintaa on raportissa kuvattu sen verran pelkistetysti, että kuva siitä, mitä tässä toimintosarjassa todella tapahtui, jää hiukan ylimalkaiseksi. Asiaa olisi auttanut, jos joistakin keskeisistä koulutusohjelmien käsittelyvaiheista, tehtäväsuorituksista ja liitynnöistä vireillä olleisiin kehittämishankkeisiin olisi annettu esimerkkejä raportin liiteosassa. Pelkistettyä raportointia voidaan kyllä perustella sillä, että kysymyksessä ei varsinaisesti ollut joidenkin teoreettisten oletusten tai väittämien empiirinen todentaminen. Lisäksi lukija pääsee osallistujien kanssa lähempään kontaktiin, kun raportissa käsitellään heidän arviointejaan mallista ja järjestetystä koulutuksesta.

K iintoisin kysymys on, kuinka toimivaksi osallistujat mallin arvioivat ensimmäisen tutustumisvaiheen perusteella. Raportin mukaan johtoryhmien edustajat kokivat mallin "yleensä ottaen helposti miellettäväksi ja toimivan tuntuiseksi'" - samalla useimmat kyllä totesivat arvioinnin vaikeaksi, kun ei mallia vielä ollut ennätetty kunnolla omaksua, saati hankkia kokemusta sen käytöstä. Viime kädessä arvioinnit ehkä osoittavatkin jonkinlaista yleismyönteisyyttä kokeilua kohtaan; pitemmälle meneviä päätelmiä en tekisi siitäkään, että enemmistö osallistujista katsoi siihenastisen koulutuksen jo vaikuttaneen sekä johtoryhmänsä että omaan työskentelyyn. Pidän hiukan yllättävänä, että vain harva vastaaja arvioi mallin teoreettisesti liian vaikeaksi jokapäiväiseen käyttöön. Omasta puolestani olisin nimittäin taipuvainen liittymään näihin epäileviin Tuomaisiin.

Strategisen kehittämistyön käytännön pulmat ja rajoitukset tulivat esille arviointia seuranneessa johtoryhmien kolmannessa koulutusvaiheessa, jonka tehtävänä oli jatkaa mallin työstämistä. (Tässä vaiheessa yksi kolmesta kuntainliitosta irtautui jatkamaan itsenäisesti.) Todettiin mm., että oppilaitosten arkirutiinit ja rinnakkaiset kehittämishankkeet vaativat aikaa ja kilpailevat osin kokeilun strategisen kehittämistyön kanssa. Erityisiä ongelmia nähtiin koulutuksen ja kehittämistyön ulottamisessa osastonjohtajien ja muun henkilös- 
tön tasolle (projektin tähän vaiheeseen kuului vasta yksi osastonjohtajille järjestetty kehittämispäivä). Raportin mukaan kehittämistyön jatkamiselle onnistuttiin joka tapauksessa jäsentämään selvät toimintalinjat ja kehittämismallin todettiin tarjoavan muutosstrategian rungon.

Omissa huomioissaan tutkija pohtii kokeilun ' 'koulutuksellisen lähestymistavan" pulmia ja arvioi, että osallistujat ovat ehkä tehneet enemmänkin koulutusta varten kuin tosiasiallisena kehittämistyönä. '’Näin koulutus kehitystyön kontekstina ei ole omiaan edistämään yhteistä vastuunottoa, hakeutumista kehitysprosessin määrätietoiseen eteenpäin saattamiseen.' Tutkijan valmiutta havaintojensa kriittiseen arviointiin osoittaa myös toisessa yhteydessä esitetty pohdinta kehittämisprojektiin liitetyn tutkimuksen vieraannuttavista efekteistä (kehittämistyön viivästyminen, koekaniinina olemisen tuntemukset).

K ehittämismallin kokoavassa arvioinnissa (luku V) Valkama kiteyttää kokeilun tuottamat kokemukset neljään päätelmään:

1) Yhteinen näkemys muutoksesta ja sen edellytyksistä ei riitä motivoimaan toimintaa. Jo analyysivaiheessa on näkemystä konkretisoitava kehittämislinjoiksi.

2) Muutos on suunniteltava ja kehittämisprosessi suhteutettava jokapäiväiseen tulokseen suuntautuvan toiminnan kulkuun. Käytännön ratkaisuksi esitetään kehittämisprosessin eteneminen sarjana strategisia projekteja.

3) Strateginen kehittäminen on integroitava siihen käytännön toiminnassa kaiken aikaa tapahtuvaan kehittymiseen, joka ilmenee esimerkiksi akuuttien ongelmien ratkaisemisena ja yksikkökohtaisina kehittämistoimina.

4) Koulutuksen ja konsultoinnin keskinäinen suhde kehittämistyön ohjaamisessa on ehkä parhaiten ratkaistavissa prosessin kulloistenkin vaatimusten mukaisena painopisteiden vaihteluna.

Valkama on näin tuonut tiivistetysti esille mallin toteuttamisen olennaisia pulmakohtia ja joutunut tarkistamaan teoreettisen mallinsa ideaa strategisen kehittämisen erkaantumisesta. Hän esittää pulmakysymyksiin täsmentyneempiäkin ratkaisumahdollisuuksia, vaikka niiden kehittely on tässä vaiheessa vielä tunnustelevaa. Erityisen tärkeänä pidän kysymystä konsultin asemasta kehittämismallin toteuttamisessa; sehän $\mathrm{mm}$. määrää ratkaisevasti mallin käyttömahdollisuuksien laajuutta. Mitä välttämättömämpää on erityisasiantuntijan osallistuminen kehittämistyöhön, sitä vaikeampaa on saada mallia laajaan jokapäiväiseen käyttöön. Sitä suurempi on samalla riski, että mallia käytetään vesitettynä, sen teoreettisia perusteita vain näennäisesti noudatellen. Nämä ongelmat jäävät raportissa mielestäni liian vähälle huomiolle. Valkama on sen sijaan kyllä yleisesti pohtinut, miten malli ja sen soveltamisesta saadut kokemukset ovat yleistettävissä muuntyyppisiin koulutusorganisaatioihin. Kun mallia ei tarjota sellaisenaan noudatettavaksi, vaan käsitteelliseksi välineistöksi " tilannekohtaisten kehitysprosessien" suunnitteluun, niin voitaneen sanoa, että tällaisena se on muutettavat muuttaen käyttökelpoinen hyvinkin monenlaisissa organisaatiorakenteissa ja suunnittelutehtävissä.
$\mathbf{R}$ aportin pääteluvussa "'Kehittyvä koulutusorganisaatio" tarkastelu siirtyy yleisemmälle tasolle ja kohdistuu koulutusorganisaatioissa tapahtuvan kehittämistoiminnan yhteiskunnallisiin kehyksiin. Valkama on niin analyysivaiheessa kuin lopputarkastelussakin tähdentänyt aiheellisesti sitä ratkaisevaa metkitystä, mikä nopeasti muuttuvalla toimintaympäristöllä on yksittäisten koulutusorganisaatioiden kehittämiselle. Juuri tällä hetkellä "muutospyörteisyyttä" aiheuttaa erityisesti valtionhallinnon johtama koulutuspoliittinen uudistustyö, tulosajattelu, ostokoulutuksen markkinajärjestelmä, hallinnon hajoittamishankkeet jne. On selvää,että koulutusorganisaatioiden omissa kehittämishankkeissa on valtion hallinto- ja rahoitusjärjestelmien uudistukset hyvin pitkälle otettava annettuina realiteetteina, oman suunnittelun reunaehtoina. Tästä huolimatta raportin ajattelutavassa on mielestäni turhaa passiivistakin tavoiterationaalisuuden sävyä. Muutoksen hallinta, joka on asetettu strategisen kehittämisen tavoitteeksi, näyttää tarkoittavan organisaation mukauttamista ympäristön muutoksiin. Koulukseen nyt ulotetun markkina-ajattelun innokkaaksi puoltajaksi Valkamaa ei kylläkään sovi leimata. Tulosajattelun yhteydessä hän huomauttaa, että koulutusorganisaatioiden tuloksia on arvioitava oppimisen kontekstissa, elämänhallintana, osaamisena työelämässä, asemina yhteiskunnassa, yritysten ja yhteisöjen toimintapotentiaaleina, ja niiden mittaamiseen eivät tuloksenteon taloudellisuuden ja tehokkuuden suoraviivaiset kriteerit sovellu.

Pääteluvussa käsitellään koulutuksen kehittämisen perusluonteisia kysymyksiä ja esitetään monia hyviä oivalluksia. Kaiken kaikkiaan tekijän ote on tässä jotenkin hapuilevampi kuin aikaisemmissa luvuissa. Vaikka tutkimus on edennyt runsaan vuoden aikana projektin aloittamisesta raportin valmistumiseen, siinä ei juuri havaitse hätiköinnin jälkeä. Poikkeuksena on ehkä pääteluku, se olisi varmaan voittanut pidemmästä kypsyttelyajasta.

Raportin rakenne noudattelee luontevasti tutkimusprosessin etenemisvaiheita. Teksti on yleensä selkeää. Taipumus epäsovinnaisiin ilmaisuihin on pidetty hallinnassa (turha niitä oli pyydellä lainausmerkkien käytöllä anteeksi!). Pyrkimys tiiviiseen esitystapaan on ehkä pääsyynä siihen, että luettavuutta paikoitellen heikentää runsas lauseenvastikkeiden käyttö ja perättäisten genetiiviattribuuttien sumat. Tiiviyden ansiopuolia taas ovat turhan rönsyilyn välttäminen ja keskittyminen pääasioihin.

$\mathbf{H}$ annu Valkaman tutkielman pääpaino on mallin teoreettisessa kehittelyssä ja siinä hänen tutkijanlahjakkuutensa on päässyt parhaiten oikeuksiinsa. Mallin koettelu on projektin tässä vaiheessa vasta alustavaa, mutta tekijä osoittaa siinä kykynsä havaintoaineiston muokkaamiseen ja jäsentelyyn samoin kuin valmiutensa objektiivisuutta tavoittelevaan kriittisyyteen.

AULIS ALANEN

Lisensiaattitutkielma on hyväksytty Tampe-
reen yliopistossa syyslukukaudella 1990 ja jul-
kaistu Tampereen yliopiston aikuis- ja nuoriso-
kasvatuksen laitoksen julkaisusarjassa 27:1991. 